HARRY POTTER AND ATTITUDES TOWARD STIGMATIZED GROUPS

The Greatest Magic of Harry Potter: Reducing Prejudice

\begin{abstract}
Recent research shows that extended contact via story-reading is a powerful strategy to improve outgroup attitudes. We conducted three studies to test whether extended contact through reading the popular best-selling books of Harry Potter improved attitudes toward stigmatized groups (immigrants, homosexuals, refugees). Results from one experimental intervention with elementary school children and from two crosssectional studies with high-school and University students (in Italy and UK) support our main hypothesis. Identification with the main character (i.e., Harry Potter) and disidentification from the negative character (i.e., Voldemort) moderated the effect. Perspective-taking emerged as the process allowing attitude improvement. Theoretical and practical implications of the findings are discussed in the context of extended intergroup contact and social cognitive theory.
\end{abstract}

Keywords: extended contact, indirect contact, Harry Potter, perspective-taking, identification with characters 
HARRY POTTER AND ATTITUDES TOWARD STIGMATIZED GROUPS

\section{The Greatest Magic of Harry Potter: Reducing Prejudice}

Differences of habit and language are nothing at all if our aims are identical and our hearts are open.

Albus Dumbledore

There is no doubt that the novels of Harry Potter, by the author J. K. Rowling, have been among the greatest successes in the history of literature and cinema industry. From June 1997, when the first book was published, until June 2011, the series of books, translated in 67 languages, had sold about 450 million copies worldwide and is the best-selling book series of all times (Wikipedia, 2014). Overall, the books have received numerous awards and their literary value has been acknowledged (e.g., Alton, 2009; Knapp, 2003). The stories of Harry Potter have inspired a number of products, ranging from videogames and toys to clothing and theme parks.

The novels of Harry Potter represent several literary genres, including not only fantasy, which is the most evident, but also romance, adventure, thriller, mystery, gothic, pulp fiction, detective fiction, all fused by Rowling in a single mosaic (Alton, 2009). The complexity and richness of the topics addressed in the novels (Mulholland, 2006) make them appealing to both children and adults (Heilman, 2009; Patrick \& Patrick, 2006). As such, it not surprising that they have stimulated debates and controversies on moral, religious and educational topics among scholars of various disciplines (Griesinger, 2002; Senland \& Vozzola, 2007).

It has been suggested that the novels have the potential to achieve a positive social impact. Knapp (2003) argues that the books can be of great appeal to children, 
who can thus be highly motivated to read them. This process can lead to educational benefits, such as improved reading ability, reading engagement and literacy

development. The appeal of a book is important, as pupils often fail to identify engaging books (Worthy, Moorman, \& Turner, 1999). Fields (2007) notes that the novels address important social, cultural and psychological issues, such as culture, society, social inequalities, love, the transition to maturity, prejudice (see also Heilman, 2009; Knapp, 2003; Whitney, Vozzola, \& Hofmann, 2005). Beers and Apple (2006; See also Fields, 2007) point out that the novels highlight a social structure where intergroup conflict is a highly salient topic. Tangentially, the topics of the books delve into social issues such as opposing identities, prejudice and conflict.

Given the impressive success of Harry Potter worldwide and the importance of the intergroup topics addressed in the novels, we aimed to test whether they have the potential to effectively achieve social goals such as the amelioration of intergroup relations. Specifically, the present research was designed to test whether the novels of Harry Potter can be used as a tool for improving attitudes toward stigmatized groups.

\section{The Novels of Harry Potter}

The series consists of seven books that follow the life of Harry Potter. At the age of 11 Harry, who is an orphan child and lives with his uncle, aunt and cousin, discovers that he is a wizard and that he will attend a school where young wizards and witches learn how to perform magic. Together with his two best friends, Harry will fight against his greatest enemy, Lord Voldemort, the most evil wizard of all times. Voldemort tried to kill Harry when he was one year old, before disappearing for many years. Harry will soon discover from Albus Dumbledore, the Headmaster of his school, that Voldemort will return. Meanwhile, Harry attends the school and grows into a talented and brave 
man. He will fight against Voldemort's return several times along the series, until he will defeat him in the final battle.

The novels are complex and speak of a world that is parallel to the "real" world of people without magic (the "muggles"). Apart from the character of Harry, which entails several important qualities such as bravery and positive personal and social values that make him stand against social inequalities and injustices (Delzescaux, 2009), another key character is Voldemort, who is the main negative character and believes that power should be held only by "pure-blood" wizards and witches, that is, only by wizards and witches born from parents with magical powers (the association between Voldemort's beliefs and Nazism are rather obvious).

The world of Harry Potter is characterized by strict social hierarchies and resulting prejudices, with obvious parallels with our society. First of all, people without magic powers are profoundly discriminated in the "wizarding world." Another stigmatized category is that of "half-blood" or "mud-blood", wizards and witches born from families where only one parent has magical abilities. Other examples of stigmatized categories are the elves (servants and slaves of wizards), the half-giants (born from one giant parent and an "ordinary" wizard or witch), the goblins (who guard the bank of wizards). These latter categories represent creatures that are not "fully" human; They are however represented by Rowling as humanized, and can thus be easily perceived as low-status human categories. Harry has meaningful contact with characters belonging to stigmatized groups. He tries to understand them and appreciate their difficulties, some of which stem from intergroup discrimination, and fights for a world free of social inequalities.

\section{Extended Contact, Outgroup Attitudes and Harry Potter}




\section{HARRY POTTER AND ATTITUDES TOWARD STIGMATIZED GROUPS}

One of the most successful approaches to improving attitudes between groups is intergroup contact (Allport, 1954; Hodson \& Hewstone, 2013; Pettigrew \& Tropp, 2011). However, strategies based on direct intergroup contact have some important limitations: They cannot be applied when there is no opportunity for contact and are often difficult and costly to put into practice (Paluck \& Green, 2009). To address these problems, researchers have recently focused on the effectiveness of indirect contact forms, such as extended contact (Wright, Aron, McLaughlin-Volpe, \& Ropp, 1997; for a recent review, see Vezzali, Hewstone, Capozza, Giovannini, \& Wöelfer, 2014). According to the extended contact hypothesis, simply knowing that an ingroup member has one or more outgroup friends is sufficient to reduce prejudice. There is now vast support for the effectiveness of extended contact both with adults (Paolini, Hewstone, Cairns, \& Voci, 2004; Stasiuk \& Bilewicz, 2013) and children (Cameron \& Rutland, 2006; Turner, Tam, Hewstone, Kenworthy, \& Cairns, 2013; See also Turner, Hewstone, Voci, Paolini, \& Christ, 2007). Extended contact has been applied in educational settings by means of ad-hoc stories involving contact between ingroup and outgroup characters (Liebkind \& McAlister, 1999). Cameron and colleagues (e.g., Cameron \& Rutland, 2006; Cameron, Rutland, Hossain, \& Petley, 2011) conducted a series of studies where English children between 5 and 11 years of age read short stories of friendship between ingroup and outgroup characters. The stories were found to improve attitudes toward various stigmatized groups, such as refugees and disabled people.

Despite their effectiveness, the aforementioned studies are based on stories created by researchers and focused on specific target groups. We believe that it is important to explore the potential effects of real, published novels in cross-group relations. The reason being, published books are accessible to everyone and, from a 
HARRY POTTER AND ATTITUDES TOWARD STIGMATIZED GROUPS

practical perspective, they can easily be included in school curricula. Vezzali, Stathi and Giovannini (2012) provided direct evidence for the role of certain types of books in improving outgroup attitudes. They found that 11-13 years old Italian children displayed improved attitudes, behavioral intentions and decreased stereotyping toward immigrants as a result of reading books where characters from different cultures had positive interactions with characters from a culture similar to that of participants.

Importantly, the effectiveness of both ad-hoc created stories and published books involving cross-group friendships may be limited due to (a) their specific focus and context and (b) the (perhaps limited) appeal they have to readers. Specifically, we argue that such stories are likely to improved attitudes only toward the target group involved in the stories themselves and may be perceived as not (or less) appealing to the public, thus reducing their potential impact (Knapp, 2003). We suggest that reading popular fantasy novels such as those of Harry Potter may help overcome the shortcomings reported above and result in improved attitudes toward various stigmatized categories for the following reasons. First, the novels are already published and do not need any type of ad-hoc preparation. Practically this facilitates their application in social and educational contexts. Second, popular books are generally appealing; In the case of the novels of Harry Potter, for example, people report being "fascinated by them" (Knapp, 2003, p. 79). Third, in fantasy books, individuals can associate fantastic characters with real-world group members. In the case of Harry Potter books, Harry has meaningful contact with stigmatized characters: As the groups to which these discriminated characters belong do not directly represent a specific realworld category, they may be more generalizable and therefore associated with various different stigmatized groups in our society. 


\section{HARRY POTTER AND ATTITUDES TOWARD STIGMATIZED GROUPS}

Whereas in previous studies that used stories as stimuli extended contact was realized via a story character belonging to the ingroup who had contact with outgroup characters, in this research extended contact is via a fantasy character (i.e., Harry Potter); This character, with whom readers can identify at a personal level, has contact with stigmatized (fantasy) groups. In other words, whereas extended contact has been operationalized as knowing ingroup members who encounter outgroup members (Wright et al., 1997), we propose a new type of extended contact, where ingroup members are replaced by a character - felt similar to the self - who is in contact with stigmatized fantasy group members.

Finding such an effect would also represent the first evidence that extended contact produces secondary transfer effects, that is the generalization of the effects of contact with one primary outgroup to attitudes toward secondary outgroup(s) not involved in the contact situation (Lolliot et al., 2013; Pettigrew, 2009; Tausch et al., 2010; Schmid, Hewstone, Kupper, Zick, \& Wagner, 2012; For an evidence of the secondary transfer effect with imagined contact, see Harwood, Paolini, Joyce, Rubin, \& Arroyo, 2011). Previously, Vezzali and Giovannini (2012) found that the secondary transfer effect also applies when the secondary outgroups (disabled, homosexuals) are dissimilar from the primary outgroup (immigrants). Our studies would considerably expand these findings, showing that (extended) contact with fantasy characters improves relations with real-world categories (which are clearly dissimilar from fantasy groups).

Our hypothesis is in line with the parasocial contact hypothesis (Schiappa, Gregg, \& Hewes, 2005), suggesting that cognitive and affective responses following exposure to media characters are similar to those produced by direct contact experiences 
(see Ortiz \& Harwood, 2007). It is also consistent with social cognitive theory (Bandura, 1997, 2002), according to which individuals, through the process of abstract modeling, can learn positive outgroup attitudes and intergroup behaviors from vicarious experiences portrayed by relevant others, also represented by media characters, and apply them in different contexts. Specifically, the theory accords a pivotal role to identification with characters: People should align with the character and his/her view of the world only when they identify with him/her. In the Harry Potter context, Harry is the main positive character, who fights against social inequality and injustice. As such, we test identification with Harry Potter as the moderator of book reading.

In addition, we explore whether individuals also modify their outgroup attitudes when distancing themselves from the negative character. In other words, we examine the moderating role of identification with Voldemort, who endorses universally negative values linked with pervasive social discrimination (for a discussion on the different values endorsed by Harry Potter and Voldemort, see Franklin, 2006). In line with the theories reported above, we expect that reading the novels of Harry Potter will have beneficial effects on outgroup attitudes only among those who identify more with Harry Potter and/or who identify less with Voldemort.

We are also interested in the processes underlying the hypothesized effect. The literature on extended contact has identified numerous mediators, such as reduced anxiety (Eller, Abrams, \& Zimmermann, 2011), positive ingroup and outgroup norms (Gomez, Tropp, \& Fernandez, 2011), inclusion of other in the self (Turner, Hewstone, Voci, \& Vonofakou, 2008). In the present study, we test perspective-taking as a potential novel mediator of extended contact. Perspective-taking, or the ability to assume the perspective adopted by another person (Stephan \& Finlay, 1999), together 
with its emotional counterpart, that is, empathy, has been shown to have beneficial effects on outgroup attitudes and intergroup behaviors (e.g., Batson, 2010; Galinsky, Maddux, Gilin, \& White, 2008; Vescio, Sechrist, \& Paolucci, 2003). Research has shown that empathy and perspective-taking can be induced by listening to or reading stories of individuals belonging to stigmatized groups, such as ethnic groups, homeless and older people (e.g., Batson et al., 1997; Galinsky \& Ku, 2004; Galinsky, Ku, \& Wang, 2005). Moreover, research has demonstrated that intergroup empathy and perspective-taking can stem from experiences of intergroup contact and are, after intergroup anxiety (Pettigrew \& Tropp, 2008), the most potent mediators of contact effects (e.g., Capozza, Vezzali, Trifiletti, Falvo, \& Favara, 2010; Swart, Hewstone, Christ, \& Voci, 2011; Vezzali, Giovannini, \& Capozza, 2010).

However, the potential role of perspective-taking as a mediator of the extended contact effects has not yet been tested (but see Andrighetto, Mari, Volpato, \& Behluli, 2012, who demonstrated that perspective-taking mediates the effects of an alternative type of extended contact, via family members, on competitive victimhood). There are several examples in the novels where Harry, during contact with characters belonging to stigmatized groups that suffer the consequences of prejudices and discrimination, tries to understand them and to improve their situation. According to social cognitive theory (Bandura, 2002), individuals exposed to vicarious experiences learn cognitive and affective responses displayed by characters through the process of symbolic interaction (Bandura, 1999) and use them in various social situations. In our case, we expect that participants will associate learned responses concerning taking the perspective of fantastic creatures with corresponding perspective-taking toward stigmatized real outgroups, which in turn should improve outgroup attitudes. 


\section{HARRY POTTER AND ATTITUDES TOWARD STIGMATIZED GROUPS}

\section{Overview of Our Research}

The aim of the present research is to examine whether reading the novels of Harry Potter improves attitudes toward stigmatized groups. To this end, we conducted three studies, based on the predictions derived by extended contact (Wright et al., 1997) and social cognitive theory (Bandura, 2002) and consistent with the theoretical premises of parasocial contact hypothesis (Schiappa et al., 2005). We considered participants across an extended life span, ranging from childhood to young adulthood. The first study is an experimental intervention realized among Italian elementary school children. The second and third studies are cross-sectional, conducted with high-school students in Italy and University undergraduates in the UK, respectively. In order to provide a stringent test for our hypotheses, we focused on three deeply stigmatized outgroups: Immigrants (Study 1), homosexuals (Study 2), refugees (Study 3). Indeed, there is evidence that prejudice toward homosexuals and ethnic minorities, such as immigrants and refugees, is strongly endorsed by Europeans (Pereira, Vala, \& Costa-Lopez, 2010; Schmid et al., 2012; West \& Hewstone, 2012; Zick, Pettigrew, \& Wagner, 2008). The realistic and symbolic threat posed by ethnic groups makes them an especially salient target for discriminatory behaviors (Cameron, Rutland, Brown, \& Douch, 2006;

Mclaren, 2003; Pehrson, Brown, \& Zagefka, 2009; Wagner et al., 2008). Notably, young children also harbor prejudicial attitudes toward immigrants (Cameron, Rutland, \& Brown, 2007; Vezzali, Giovannini, \& Capozza, 2012), and it is therefore essential to tackle them from a young age (Cristol \& Gimbert, 2008). With respect to attitudes toward homosexuals, prejudices toward gays and lesbians are generally evident in Europe (Kite \& Whitley, 1996; Zitek \& Hebl, 2007) and prejudice toward homosexuals 
is especially high in Italy (Eurobarometer, 2012); It is therefore important to examine strategies to improve attitudes toward this stigmatized group.

In all three studies we tested the moderating role of identification with the main positive and negative characters. In particular, we expect that reading the novels of Harry Potter will have positive effects only among those who identify more with Harry Potter and/or who identify less with Voldemort. In the third study we also examine perspective-taking as a mediator of book reading.

In all studies, in order to provide a more severe test for our hypotheses, we statistically controlled for the number of Harry Potter films watched. This variable might correlate positively with number of Harry Potter books read, and might concur to explain part of the variance of the outcome variables.

\section{Study 1}

We conducted an experimental intervention among Italian elementary school children, based on reading passages from the books of Harry Potter and discussing them with a research assistant. Based on the condition, in each of six sessions children read and then discussed with the researcher passages of the novels of Harry Potter related (experimental condition) or unrelated (control condition) to the theme of prejudice, before being administered (one week after the last session) a questionnaire with the dependent variables. Prior attitudes toward immigrants were controlled for. Furthermore, we statistically controlled for the number of Harry Potter books read or films watched by each child. Gender was included as a further control variable.

\section{Method}

\section{Participants and Procedure}




\section{HARRY POTTER AND ATTITUDES TOWARD STIGMATIZED GROUPS}

Participants were 34 Italian fifth-grade elementary school children (13 males, 21 females) from a school located in Northern Italy. We obtained teachers' and parents' consent prior to conducting the study.

In a first phase, children were administered a questionnaire assessing their attitudes toward immigrants. Then, they were divided into small groups of five to six children and met with the researcher once a week for six consecutive weeks. In each session, the researcher read the selected passages from the novels of Harry Potter (following the book sequence). As mentioned above, there were two conditions. In the experimental condition, the selected passages related to issues of prejudice and their consequences. For instance, children read a passage from Harry Potter and the Chamber of Secrets where Draco Malfoy (a negative character, schoolmate of Harry Potter) insults Hermione, one of the two best friends of Harry (together with Ron), by calling her "filthy little Mudblood" (Rowling, 1998, p. 86). In the same session, they read about Hermione's reaction, who felt humiliated despite being the most talented young witch in the school, and about the angry reactions of her friends, including Harry. In the control condition, passages were unrelated to prejudice. In one session, for instance, participants read a passage where Harry buys his first magic wand.

The passages, selected by the researchers, were evaluated by independent judges (University students) to be highly related (experimental condition) or totally unrelated (control condition) to the issue of prejudice. Moreover, no differences were found between the passages in the control and experimental conditions regarding how nice and interesting they are.

Prior to any reading, the researcher briefly summarized the plot that preceded the passage, so as to facilitate children's understanding and link the passage with the whole 
story. After reading the relevant passage, children took part in a group discussion led by the researcher, focusing on what they had just read. In the experimental condition the discussion thus focused on the prejudicial acts committed against stigmatized groups, on their consequences such as the sufferings produced in stigmatized group members, on the role of Harry Potter in addressing these injustices. In the control condition the discussion focused on the specific passage read (for instance, in one session where the story concerned Harry playing Quidditch, the most important wizarding sport, participants discussed their preferred sport activities, etc.). One week after the last session, children were administered a questionnaire with the dependent variables.

\section{Measures}

Unless otherwise indicated, responses to all items were given on a 5-step scale, anchored by 1 (not at all) and 5 (very much).

Manipulation check. To ensure that the passages in the experimental and control conditions were of similar appeal to children, four items assessed the extent to which the passages were nice, interesting, funny, difficult to understand.

Attitudes toward immigrants (administered before and after the intervention). We adapted two items from the scale by Liebkind and McAlister (1999) ("It would be great if there were more pupils from other countries in my school"; "It would be great if there were more pupils from other countries in my neighborhood"). Correlation between the two items after the intervention was high $(r=.84, p<.001)$. Although the correlation between the two items before the intervention was low $(r=.16)$, test-retest reliability was significant $(r=.43, p<.05)$. Thus, we created a composite score for the two items both before and after the intervention: Higher scores indicate more positive attitudes toward immigrants. ${ }^{1}$ 


\section{HARRY POTTER AND ATTITUDES TOWARD STIGMATIZED GROUPS}

Identification with Harry Potter and with Voldemort. To assess identification with Harry Potter, two items were used, adapted by Eyal and Rubin's (2003) scale of identification with media characters ("I'd like to be like Harry"; "I wish I could be more similar to Harry"). The two items were averaged $(r=.41, p<.05)$, with higher scores reflecting stronger identification with Harry Potter. Identification with Voldemort was assessed with the same two items $(r=.84, p<.001)$.

Harry Potter books read and films watched. Children were presented with a list of the Harry Potter published books (seven books) and films (six films; At the time of data collection, between December 2009 and January 2010, only six out of eight films were released), and were asked to indicate the books they had read and the films they had watched.

\section{Results}

Read passages were rated as nice $(M=4.41, S D=0.82)$, interesting $(M=4.32$, $S D=0.81)$, funny $(M=3.53, S D=1.26)$, not difficult to understand $(M=1.27, S D=$ 0.45). Importantly, mean scores did not differ between experimental and control conditions, $t \mathrm{~s}<1.52, p \mathrm{~s}>.13$. Thus, subsequent differences between conditions cannot be attributed to a greater liking of read passages in one condition compared to the other. Preliminary analyses, moreover, revealed that attitudes toward immigrants assessed prior to the intervention, number of Harry Potter books read and films watched, identification with Harry Potter and Voldemort, did not differ between experimental and control conditions, $t \mathrm{~s}<1.57, p \mathrm{~s}>.12$. Descriptives for the two conditions are presented in Table 1. Interestingly, identification with Harry Potter was not correlated with identification with Voldemort, $r=-.03, p=.87$, suggesting that identifying with the former is not the opposite from identifying with the latter. 


\section{HARRY POTTER AND ATTITUDES TOWARD STIGMATIZED GROUPS}

[Table 1]

To test our hypotheses, two hierarchical regressions were conducted (one for identification with Harry Potter as the moderator, the other for identification with Voldemort as the moderator). In the first step, we entered condition (coded 1 for the experimental and 0 for the control condition) and the hypothesized moderator (centered). As control variables, we included prior attitudes toward immigrants, gender, Harry Potter books read and films watched. In the second step, we added the two-way interaction between experimental condition and the moderator. The outcome variable was attitudes toward immigrants as reported after the intervention.

First, we tested moderation by identification with Harry Potter. Results revealed a main effect of gender, $\beta=.36, p<.05$, indicating that females had more positive attitudes toward immigrants than males; And a main effect of initial attitudes, $\beta=.37, p$ $<.05$. As expected, the two-way interaction between experimental condition and identification with Harry Potter was significant, $\beta=.51, p<.05$. Simple slope analyses showed that reading the passages from Harry Potter books related to improved attitudes toward immigrants among children who identified more with Harry Potter $(+1 S D), b=$ $1.04, t=2.25, p<.05$. The effect of the experimental condition was non-significant for participants who identified less with Harry Potter $(-1 S D), b=-0.46, t=1.06, n s$. The regression model including the interaction term explained $47 \%$ of the total variance. Thus, our prediction was fully supported: Reading passages of Harry Potter related to prejudice, relative to the control condition, improved outgroup attitudes, over and above the effects of control variables. ${ }^{2}$ 


\section{HARRY POTTER AND ATTITUDES TOWARD STIGMATIZED GROUPS}

When testing identification with Voldemort as the moderator, only one main effect emerged: Identification with Voldemort was associated with more negative outgroup attitudes, $\beta=-.46, p<.05$. None of the other effects was significant, $p \mathrm{~s}>.22$.

\section{Discussion}

The present study provides initial evidence regarding the effectiveness of reading the stories of Harry Potter on the improvement of outgroup attitudes for participants who identify highly with Harry Potter. Results revealed that a structured intervention based on reading passages related to prejudice and conducted among Italian elementary school children improved attitudes toward immigrants (compared to a control condition where children read passages unrelated to prejudice) for children who identified more with the main positive character. Importantly, these effects were obtained by controlling for relevant variables. Notably, the moderating role of identification with the positive character is in line with social cognitive theory (Bandura, 1997) and extended contact hypothesis (Wright et al., 1997). Identification with the negative character did not act as a moderator. Possibly, perceived similarity with the main positive character (who has an age similar to that of participants) and dissimilarity from the negative character (who is depicted as an adult) may have played a role (Bandura, Ross, \& Ross, 1961). This possibility will be discussed more in detail in the General Discussion. Moreover, stories presented in the experimental condition were based on Harry's contact with stigmatized group members, rather than on Voldemort's actions, so it is not surprising that participants' attitudes improved only when they identified with Harry Potter.

\section{Study 2}


HARRY POTTER AND ATTITUDES TOWARD STIGMATIZED GROUPS

The aim of the second study was to replicate the effects found in Study 1 with a different age group (high-school students) and a different target outgroup. In order to test the generalizability of the effect to different stigmatized categories, this study focused on attitudes toward homosexuals, another highly stigmatized group (see Hodson, Harry, \& Mitchell, 2009; Vezzali \& Giovannini, 2012).

As control variables, we considered age and gender, number of books read per year (excluding those of Harry Potter) and number of hours spent each day watching television. Indeed, we aimed to examine whether the improvement of outgroup attitudes is a consequence of the mere act of reading or if it is specifically related to reading Harry Potter. Accordingly, exposure to television (rather than specifically watching Harry Potter films) may affect outgroup attitudes. Prior quantity and quality of contact with the outgroup were controlled for, given the major role of these variables (especially quality of contact) in influencing outgroup attitudes (Hodson \& Hewstone, 2013; Pettigrew \& Tropp, 2011). We also statistically controlled for the number of Harry Potter films watched (and for the interaction of this variable with character identification). Showing that reading Harry Potter improves attitudes over and above prior contact with homosexuals and the other control variables would provide critical support to our hypotheses.

\section{Method}

\section{Participants and Procedure}

Participants were 117 students (46 males, 71 females) attending a high school located in Northern Italy. Age of participants ranged from 16 to 20 years $(M=17.39$, $S D=0.94$ ). Participants were administered two questionnaires during classes (in counterbalanced order) for two ostensibly unrelated studies. One questionnaire was 


\section{HARRY POTTER AND ATTITUDES TOWARD STIGMATIZED GROUPS}

presented as an investigation concerning the liking of the series of Harry Potter; It contained only measures related with Harry Potter and with book reading and watching television in general. The other was introduced as a research on social attitudes, and it included items concerning relations with homosexuals.

\section{Measures}

\section{Questionnaire 1}

Harry Potter books read and films watched. The two measures were identical to those used in Study 1. In this case, however, the response scale for Harry Potter included seven films, as data were collected when the seventh film had already been released.

Identification with Harry Potter and Voldemort. We adapted three 5-step items $(1=$ not at all $; 5=$ very $m u c h)$ for each of the two characters from the scale of identification with media characters (Eyal \& Rubin, 2003), similar to those used in Study 1 ("I wish I could be more similar to Harry/Voldemort"; "Harry/Voldemort represents the type of person I'd like to be"; "I often think of how it would be to be like Harry/Voldemort"). We created a composite score of identification with Harry Potter $($ alpha $=.78)$ and Voldemort $($ alpha $=.86)$, with higher scores reflecting stronger identification with each of the two characters. As the distribution of these measures was highly skewed, they were subjected to a root-square transformation (see Cehajic, Brown, \& Castano, 2008; Vorauer \& Sasaki, 2012).

Books read per year and hours spent each day on television. The following items were used: "On average, how many books (excluding those of Harry Potter) do you read every year?”; "On average, how many hours do you spend every day watching television?”. For both items, participants responded on a 5-step scale, ranging from 1 
HARRY POTTER AND ATTITUDES TOWARD STIGMATIZED GROUPS

(zero) to 5 (at least seven); The other degrees were 2 (one or two), 3 (three or four), 4 (five or six).

Questionnaire 2

Attitudes toward homosexuals. An evaluation thermometer was used, in which participants rated homosexuals on a scale ranging from 0 (extremely unfavorable) to 100 (extremely favorable).

Prior contact with homosexuals. We assessed both quantity and quality of contact with homosexuals. For quantity of contact, we asked participants how often they have contact with homosexuals, by using a 5 -step scale $(1=$ never; $5=$ very often $)$. To assess quality of contact, participants indicated on a 5-step scale $(1=$ not at all; $5=$ very much) how pleasant their encounters with homosexuals are.

\section{Results}

[Table 2]

Means, standard deviations and correlations among measures are presented in Table 2. We note that, replicating Study 1, identification with Voldemort and with Harry Potter were not correlated. To test our hypotheses, two hierarchical regression analyses were conducted. In the first, we tested the moderating role of identification with Harry Potter; In the second, identification with Harry Potter was replaced by the other hypothesized moderator (i.e., identification with Voldemort). In both regressions, in the first step we entered number of Harry Potter books read and films watched (centered), the moderator variable (centered), number of books read per year, hours spent each day on television, age, gender, quantity and quality of contact with homosexuals. In the second step, the two-way interactions of Harry Potter readings and 


\section{HARRY POTTER AND ATTITUDES TOWARD STIGMATIZED GROUPS}

films watched with the moderator were added. The dependent variable was attitudes toward homosexuals.

When testing identification with Harry Potter as the moderator, a main effect of gender emerged, indicating that females had more favorable attitudes toward homosexuals than males, $\beta=.22, p<.01$. Moreover, in line with the literature on intergroup contact, we found a main positive effect of quality of contact, $\beta=.50, p<$ .001. In line with predictions, the expected two-way interaction between Harry Potter books read and identification with Harry Potter was significant, $\beta=.16, p<.05$. Simple slope analysis revealed that reading the books of Harry Potter was associated with more positive outgroup attitudes among participants who identified more with Harry Potter, $b$ $=2.48, t=2.13, p<.05$, but not among those who identified less, $b=-1.02, t<1$. The model including the interaction between number of Harry Potter books read and identification with Harry Potter accounted for $50 \%$ of the total variance.

In the second regression model, testing identification with Voldemort as the moderator, once again, results revealed a main effect for gender, $\beta=.22, p<.01$, and for quality of contact, $\beta=.50, p<.001$. None of the other effects was significant, $p \mathrm{~s}>$ .17.

\section{Discussion}

This study provides support to the hypothesis that reading the novels of Harry Potter is associated with improved attitudes toward a stigmatized group such as homosexuals among a sample of high-school students. In particular, in line with extended contact principles (Wright et al., 1997) and social cognitive theory (Bandura, 2002), book reading improved attitudes toward homosexuals only among those more 
identified with the positive character. The fact that the effects were obtained by considering several relevant control variables adds confidence in these results.

Again, identification with Voldemort did not moderate the effects of book reading for this age group (mostly teenagers). This result may depend on the perception of the adult Voldemort as a less relevant model than the child/teenager Harry (Bandura et al., 1961; See General Discussion).

\section{Study 3}

In order to increase the external validity and generalizability of our results, we conducted an online cross-sectional study with a sample of undergraduate University students in UK, which considered a further stigmatized outgroup: Refugees. In this study, we also aimed to understand the underlying factors of potential effects of Harry Potter books on outgroup attitudes, so perspective-taking was tested as the mediating process. Our hypothesis is that reading the novels of Harry Potter will enhance perspective-taking toward refugees only among those identifying more with the positive character and/or distancing themselves more from the negative character; Increased perspective-taking should then be positively associated with more positive attitudes toward refugees. Thus, we predict a moderated mediation effect, where identification with Harry and/or Voldemort is the moderator and perspective-taking toward refugees is the mediator (Muller, Judd, \& Yzerbyt, 2005; Preacher, Rucker, \& Hayes, 2007).

As in Study 2, we statistically controlled for age, gender, number of books read per year (excluding those of Harry Potter), number of hours spent each day watching television, quantity and quality of contact, number of Harry Potter films watched (and its interaction with character identification).

\section{Method}


HARRY POTTER AND ATTITUDES TOWARD STIGMATIZED GROUPS

\section{Participants and Procedure}

Seventy-five undergraduate students at a University located in the south east of England took part in the study. Four participants were excluded because of an excessive number of missing data, leaving a final sample of 71 participants (13 males, 58 females). Age ranged from 18 to 44 years $(M=20.15 ; S D=3.96)$. Participants were administered two online questionnaires (in counterbalanced order) for two ostensibly unrelated studies. As in the previous study, one questionnaire concerned the series of Harry Potter and book reading and watching television in general; The other included items concerning relations with the outgroup. Participants volunteered to take part in this study in exchange for research credits.

\section{Measures}

\section{Questionnaire 1}

The measures of Harry Potter books read and films watched, identification with Harry Potter (alpha $=.84)$ and with Voldemort $($ alpha $=.85)$, books read per year and hours spent each day on television, were the same as in Study 2. The distribution of identification with Voldemort was highly skewed; This variable was therefore subjected to a square-root transformation.

\section{Questionnaire 2}

Perspective-taking toward refugees. Perspective-taking was assessed with three items, adapted by Aberson and Haag (2007) and by Vezzali and Giovannini (2012) (“I think I understand the way refugees see the world"; "In general I'm able to jump into refugees' shoes"; "It's difficult for me to see things from the point of view of refugees," reverse-scored). The 5-step scale ranged from 1 (not at all) to 5 (very much). Ratings 
HARRY POTTER AND ATTITUDES TOWARD STIGMATIZED GROUPS

were averaged (alpha $=.62)$ : Higher scores denote stronger perspective-taking toward refugees.

Attitudes toward refugees. A measure of social distance was used, adapted by Esses and Dovidio (2002), consisting in five 5-step items ( $1=$ not at all; $5=$ very much $)$ measuring participants' willingness of disclosing personal information to an outgroup member and accepting him/her as a neighbor, close friend, classmate, professor (alpha = .94). Responses were coded so that higher scores indicate more willingness to engage in contact behaviors with the outgroup (if provided with the opportunity) and, thus, more positive attitudes.

Prior contact with refugees. Quantity and quality of contact with refugees were assessed with the same items used in Study 2.

\section{Results}

Means, standard deviations and correlations among variables are in Table 3.

\section{[Tables 3, 4]}

To test predictions, we applied hierarchical regression. First, we conducted two hierarchical regressions to examine whether reading the novels of Harry Potter was associated with perspective-taking depending on the level of identification with Harry Potter or with Voldemort (mediator variable models). In the first step, the variables entered were: Number of Harry Potter books read and films watched (centered), identification with Harry Potter or with Voldemort (centered), number of books read per year, hours spent each day on television, quantity and quality of contact with refugees, age, gender. In both regressions, we statistically controlled for identification with the other main character (Voldemort or Harry Potter respectively), because of the correlation between the two variables (Table 3). In the second step, the two-way 


\section{HARRY POTTER AND ATTITUDES TOWARD STIGMATIZED GROUPS}

interactions of number of Harry Potter books read and films watched with character identification were added. The same regression models were then conducted using outgroup attitudes as the dependent variable (dependent variable models). Results of the four regression models are summarized in Table 4. When perspective-taking was the dependent variable, the expected interaction between number of Harry Potter books read and identification with Voldemort was significant. Simple slope analyses indicated that the number of Harry Potter books read was positively associated with perspectivetaking toward refugees among participants less identified with Voldemort, $b=.13, t=$ $2.10, p<.05$. For those more identified with the negative character, the relation between Harry Potter books read and perspective-taking was non-significant, $b=-.10, t=1.54, p$ $=.13$. In addition, results revealed a marginal interaction between number of Harry Potter films watched and identification with Voldemort, which however did not reach conventional levels of statistical significance.

When using outgroup attitudes as the dependent variable (Table 4), unexpectedly, the interaction between Harry Potter films watched and identification with Voldemort was significant. Simple slope analyses indicated that the number of Harry Potter films watched was negatively associated with attitudes toward refugees among participants less identified with Voldemort, $b=-.23, t=2.88, p<.01$; The association between Harry Potter films watched and outgroup attitudes was nonsignificant for those more identified with the negative character, $b=.04, t<1$.

We then tested our moderated mediation hypothesis (Muller et al., 2005; Preacher et al., 2007) to examine whether Harry Potter books read (independent variable) affected attitudes toward refugees (dependent variable) via perspective-taking toward refugees (mediator) depending on the level of character identification 


\section{HARRY POTTER AND ATTITUDES TOWARD STIGMATIZED GROUPS}

(moderator). Identification with Voldemort was used as the moderator, since no moderation effects emerged for identification with Harry Potter (Table 4). Variables included in the model testing effects on outgroup attitudes were the same shown in Table 4, with the addition of perspective-taking. To perform this analysis, we used the PROCESS macro for SPSS provided by Hayes (2012, Model 8). Results revealed that, consistent with the mediation hypothesis, perspective-taking was associated with improved outgroup attitudes, $\beta=.33, p<.01$. The interaction of identification with Voldemort with number of Harry Potter books read, $\beta=-.04, t<1$, and with number of Harry Potter films watched, $\beta=.22, t=1.63, p>.11$, were non-significant. In line with predictions, when identification with Voldemort was lower (-1 SD), the $95 \%$ bootstrap confidence interval (ranging from .004 to .101) excluded 0, thus indicating a significant indirect effect. In contrast, when identification with Voldemort was high $(+1 S D)$, the $95 \%$ bootstrap confidence interval (ranging from -.112 to .002) included 0, indicating absence of mediation effects. The variance explained by the final model was $48 \%$.

\section{Discussion}

This study provides evidence that supports the effect of reading the books of Harry Potter on relations with refugees among University students, as well as support for the mediating role of perspective-taking and for the moderating role of identification with the negative character. In line with predictions, Harry Potter book reading was positively associated with perspective-taking toward refugees only among those less identified with Voldemort; Perspective-taking, in turn, was associated with improved attitudes toward refugees. Again, the robustness of these effects is demonstrated by the fact that they emerged by considering several control variables. 


\section{HARRY POTTER AND ATTITUDES TOWARD STIGMATIZED GROUPS}

The fact that, in contrast with previous studies, identification with Harry Potter did not moderate the results may depend on the perception of Harry as a less relevant model for the age group included in the study. Indeed, University students may feel less similar to a character depicted as a child that grows into a young teenager (Bandura et al., 1961; See also General discussion).

\section{General discussion}

Results from one experimental intervention and two cross-sectional studies show that reading the novels of Harry Potter improves attitudes toward stigmatized groups among those more identified with the main positive character (Studies 1 and 2) and those less identified with the main negative character (Study 3). We also found evidence for the role of perspective-taking as the process allowing the improvement of outgroup attitudes. These findings were obtained by considering three samples, in two European countries (Italy and UK), covering an extended age range from elementary school children to high-school to University students. Moreover, we considered several control variables and we employed different measures of attitudes toward three different, highly stigmatized groups: Immigrants (Study 1), homosexuals (Study 2), refugees (Study 3).

\section{Theoretical implications}

Previous research demonstrated positive effects of extended contact on intergroup relations through story reading (Cameron \& Rutland, 2006). We have taken a step further, testing the effect of reading already published, commercial books, generally more complex than ad-hoc created stories. In this research we proposed and found evidence for a new type of extended contact, that is via a fantasy character. Previous research found that knowing an ingroup member (or character, if extended contact was via story reading) who had contact with outgroup members improved 
HARRY POTTER AND ATTITUDES TOWARD STIGMATIZED GROUPS

outgroup attitudes (Cameron \& Rutland, 2006; Wright et al., 1997). Our findings showed that extended contact is also effective when it is via a character who does not belong to the ingroup (wizards do not exist), but who at the same time is seen as similar to the self. In addition to identification with this character, effects also depend on disidentification from the main negative character. Indeed, if participants also identify with the negative character, then the effectiveness of the intervention is severely compromised (see below).

These results also represent the first evidence that secondary transfer effects (Pettigrew, 2009) apply to extended contact since more positive attitudes were generalized toward groups that were not involved in the indirect contact situation. Moreover, our results demonstrate that contact with fantasy characters can improve attitudes toward dissimilar outgroups (see also Vezzali \& Giovannini, 2012). Unfortunately, we did not assess attitudes toward fantasy characters, so we lack direct evidence on the processes underlying this specific type of secondary transfer effect.

Our results also support the parasocial contact hypothesis (Schiappa et al., 2005): Exposure to media characters elicited cognitive and affective experiences similar to those produced by real contact. They are also in line with social cognitive theory (Bandura, 2002): Participants observed the positive attitudes and behaviors of Harry Potter toward stigmatized fantastic groups, and projected them onto real stigmatized categories only when they identified with the main positive character (Studies 1 and 2). We also found evidence for a new moderator of extended contact, disidentification from the main negative character (Study 3). This finding again supports and extends social cognitive theory (Bandura, 2002), by showing that people form attitudes not only by conforming to positive relevant others, but also by distancing themselves from negative 


\section{HARRY POTTER AND ATTITUDES TOWARD STIGMATIZED GROUPS}

relevant others. It is worth noting that identification with the negative character did not moderate the effects of book reading in Studies 1 and 2, whereas identification with the positive character did not have moderating effects in Study 3. We believe similarity (and dissimilarity) between the participants and the fictional role models might have played a role in this. As social cognitive theory underlines, similarity is an important factor for imitation of behavior (Bandura, 1997; Bandura et al., 1961). The books start with Harry being a child and continue until he is a teenager. Children (Study 1) and teenagers (Study 2) that participated and Harry have a similar age, whereas Voldemort is portrayed as an adult. This means that Harry is probably a relevant model for children, but Voldemort is not. In other words, independently by absolute levels of identification with the two characters, identification with Harry Potter may be more relevant for children than identification with Voldemort. This would explain why book reading guides improvement of outgroup attitudes in Studies 1 and 2 only based on identification with Harry Potter. On the other hand, adult participants in Study 3 may have found a child/young teenager character (i.e., Harry Potter) less relevant as a role model. Instead, dissimilarity from the main (adult) negative character might have been more relevant to them. In other words, adults may have based their attitudes more on disidentification from the negative character rather than on identification with the positive character because of perceived dissimilarity with the role model, independently of absolute level of identification with the two characters. As such, it is not surprising that in Study 3 book reading was more effective for those less identified with Voldemort. Possibly for these participants, items based on agreement with positive values supported by Harry Potter, rather than on identification with Harry Potter, may have had a moderating role. We note that absolute levels of identification with the 


\section{HARRY POTTER AND ATTITUDES TOWARD STIGMATIZED GROUPS}

characters, for adolescents (Study 2) and adults (Study 3), are rather low; It is likely that, in general, partially supporting our interpretations, these participants may be reluctant to admit similarity to characters of children's books. In any case, our analyses testing moderation by character identification did not consider absolute levels of identification (which may be misleading), but relative levels of identification (i.e., comparing those more vs. less identified with the two main characters).

Notably, we argue that identifying with the positive character is not the opposite of identifying with the negative character. Indeed, the two types of identification were uncorrelated in Studies 1 and 2, and only moderately positively correlated in Study 3. The fact that the two types of identification were not inversely related is not surprising. The books delve consistently into the mentality, values and beliefs of the two characters, with the underlying but key message being that positive and negative aspects of the self coexist in people; Also very positive characters like Harry Potter hide obscure traits and tendencies. We believe this to be a complex message that older rather than younger individuals are more likely to perceive.

Our results indicate perspective-taking as the mediating process of book reading. Again, in addition to being in line with literature on intergroup contact (Hodson \& Hewstone, 2013), these findings support social cognitive theory (Bandura, 2002): Participants reading about Harry Potter's interactions with characters belonging to stigmatized groups may have learnt to take the perspective of discriminated group members and, in turn, applied this enhanced ability to understand disadvantaged groups to real-world outgroup categories. Results also support the parasocial contact hypothesis (Schiappa et al., 2005): Contact via fictional characters improved outgroup attitudes by 
HARRY POTTER AND ATTITUDES TOWARD STIGMATIZED GROUPS

eliciting a cognitive process similar to that activated in real contact (i.e., perspectivetaking).

Although perspective-taking allowed improvement of attitudes toward stigmatized groups, other processes that underlie the effects of various forms of indirect contact could also be involved, such as reduced intergroup anxiety (Turner et al., 2008), inclusion of the other in the self (Cameron et al., 2006), and intergroup self-disclosure (Turner, Hewstone, \& Voci, 2007). Future studies should include more potential mediating factors so as to identify the key processes underlying the effects of book reading.

It should be noted that, although we found that the effects of story reading on outgroup attitudes were allowed by increased perspective-taking toward stigmatized groups, story reading may have increased participants' general ability to take the perspective of others. Kidd and Castano (2013) found in a series of studies that reading literary fiction (like Harry Potter books are assumed to be; e.g., Alton, 2009; Knapp, 2003), compared to reading popular fiction, reading non-fiction, or no-reading, increases Theory of Mind (ToM), that is, individuals' ability to understand the subjective mental state of other people (Premack \& Woodruff, 1978; Saxe, Carey, \& Kanwisher, 2004). As stated by the authors, "literary fiction [...] uniquely engages the psychological processes needed to gain access to characters' subjective experiences. Just as in real life, the worlds of literary fiction are replete with complicated individuals whose inner lives are rarely easily discerned but warrant exploration [...] Readers of literary fiction must draw on more flexible interpretive resources to infer the feelings and thoughts of characters" (p. 378). Unfortunately, since we did not assess the dimensions conceptualized by ToM, it is not possible to state that reading Harry Potter 
improved perspective taking toward the outgroup as a consequence of an improved capability of understanding others' inner lives.

One could argue that the fact that the effect of book reading was moderated by identification with main characters, rather than having a direct effect, limits the significance of the results. However, we do not consider this to be the case. Indeed, vicarious or indirect experiences can produce attitude change if they are based on observation of only relevant characters, with whom one can identify (Bandura, 2002). Similarly, according to extended contact principles, extended contact effects are stronger when there is a close psychological relationship with the individual through which extended contact is realized (Tausch, Hewstone, Schmid, Hughes, \& Cairns, 2011; Wright et al., 1997). Kaufman and Libby (2012) proposed the concept of "experience-taking," through which "readers lose themselves and assume the identity of the character, adopting the character's thoughts, emotions, goals, traits, and actions and experiencing the narrative as though they were that character" (p. 2). Our findings extend this concept, by showing that individuals change their attitudes following book reading not only when they take the perspective (i.e., identify) with the positive character, but also when they disidentify from the negative character.

In Study 3, a significant interaction between number of Harry Potter films watched and identification with Voldemort emerged with respect to outgroup attitudes. However, the fact that effects of film watching were found only in this study suggests that the effects produced by this variable are inconsistent. Future research may address more closely the effect of watching highly popular fantasy movies on outgroup attitudes. 


\section{HARRY POTTER AND ATTITUDES TOWARD STIGMATIZED GROUPS}

It is worth noting that, although our studies demonstrated that reading Harry Potter novels ameliorated already moderately positive (or not excessively negative) attitudes toward stigmatized outgroups, reading the novels can potentially tackle actual prejudice-reduction. Indeed, since disadvantaged groups such as those considered in the present research are often targets of prejudice (Sidanius \& Pratto, 1999), our results suggest that reading Harry Potter may effectively help in reducing prejudice directed at these outgroups. Moreover, attitudes toward the ingroup tend to be more positive than attitudes toward the outgroup, even when outgroup attitudes are moderately positive (Tajfel \& Turner, 1979). This may be the case in the intergroup contexts we considered. In other words, prejudice may not be evident when intergroup attitudes are considered in absolute terms, but may become apparent when considered in relative terms. This differential evaluation may easily transform into actual discrimination (Nier \& Gaertner, 2012); Thus, we argue that reducing the ingroup-outgroup differential evaluation is crucial.

\section{Practical implications}

Educational interventions based on reading fantasy books that have characteristics similar to those of the Harry Potter series may improve relations with several types of stigmatized groups. The role of educators is particularly important for young children, for whom it might be more difficult to read individually and comprehend the meaning of complex books. In this case, educators can focus on specific passages strongly related to issues of prejudice, like we have done in Study 1. For adolescents and young adults, simply encouraging the reading of this type of books may be sufficient to improve outgroup attitudes. Eventually, educators can organize discussion groups following the readings so as to reinforce their effects. This way, 


\section{HARRY POTTER AND ATTITUDES TOWARD STIGMATIZED GROUPS}

encouraging book reading and incorporating it in school curricula may not only increase the students' literacy levels, but also enhance their prosocial attitudes and behaviors. It should be noted that individual difference variables may play a role in determining the effectiveness of book reading. For instance, the effect of reading fantasy books (like Harry Potter) on improved outgroup attitudes may be stronger among individuals low in trait psychological reactance (Brehm \& Brehm, 1981; Hong \& Faedda, 1996). In contrast, outgroup attitudes should be more difficult to change for individuals more inclined to resist persuasive messages (i.e., those high in trait psychological reactance).

An important aspect that may reinforce the effectiveness of reading the stories of fantasy books, in which the issues of prejudice are clearly implied, concerns their lack of direct reference to real-world groups. Since many fantasy novels do not explicitly refer to any type of real group or category, they address general issues of prejudice in an indirect way, thus overcoming the barrier of direct and explicit attempts to modify outgroup attitudes, which can precipitate people's defensive reactions and are subject to political correctness.

\section{Limitations}

A key limitation relates to the fact that Studies 2 and 3 are correlational, and thus cannot strictly allow us to draw causal relations between the variables. However, Study 1 demonstrates that Harry Potter stories presented in a structured intervention have a causal effect on improvement of outgroup attitudes, when children identify with the positive character. In addition, since Harry Potter is generally perceived as a fictional book and not as a book concerning intergroup relations and prejudice, it is unlikely that more prejudiced individuals avoided reading these novels, i.e. it would be more likely that more prejudiced people avoid reading books centered on intercultural topics, but 
their ideology would not directly prevent them from reading fantasy books. Moreover, longitudinal (e.g., Eller et al., 2011) and experimental (e.g., Cameron \& Rutland, 2006) evidence shows that extended contact causally affects outgroup attitudes. Furthermore, in Study 1 it is not possible to differentiate the effects of reading the Harry Potter passages from those produced by the discussion led by the researcher. Discussion can be an important part of experimental field interventions that can strengthen their effects (Fisher, 1968; Meleady, Hopthrow, \& Crisp, 2013), although this is not always the case. For instance, P. J. Johnson and Aboud (2013) conducted an intervention based on reading stories of cross-group friendship between an ingroup and an outgroup character among White children from five to eight years. Their results showed that attitudes toward Blacks did not change based on whether the researcher reinforced the message of the story (a condition conceptually similar to our experimental condition in Study 1) or instead merely read the story. This finding indirectly supports the idea that story reading may also be effective when the message is not followed by a discussion. In any case, future studies should try to isolate the net effect of the intervention from that of post-discussion (Kelman \& Fisher, 2003; Paluck \& Green, 2009). For instance, the inclusion of two additional conditions where children merely discuss prejudice or where the reading of Harry Potter passages is not followed by group discussion would help disentangle the effects of Harry Potter reading from that of post-discussion. ${ }^{3}$ An additional limitation is that our studies do not provide direct evidence that fantasy characters (who do not represent specific real-world categories) are associated with more real-world groups than characters actually belonging to real-world groups (thus strengthening the effects of book reading by reaching a larger number of outgroups). Future studies may directly compare stories where extended contact is with fantasy 
HARRY POTTER AND ATTITUDES TOWARD STIGMATIZED GROUPS

characters or with characters belonging to real-world groups, in order to test this fascinating possibility.

Finally, this research has only focused on the popular best-seller of Harry Potter; It is important to identify and test other popular novels that can have similar effects and that can be equally appealing to young readers. Related to this point, we note that we did not control for the effects of reading other fictional books where positive and negative characters can be easily identified. However, we controlled for general book reading because education in general (e.g., Bilali \& Vollhardt, 2013) and book reading in particular (D. R. Johnson, Huffman, \& Jasper, 2014; D. R. Johnson, Jasper, Griffin, \& Huffman, 2013; Vezzali, Stathi, et al., 2012) have been shown to be associated with reduced prejudice. Although this research focused on Harry Potter books as they are representative of fiction literature with large-scale appeal to the public, similar research can focus on other popular published fictional books. 
HARRY POTTER AND ATTITUDES TOWARD STIGMATIZED GROUPS

\section{Footnotes}

1. We excluded from the scale a third, reverse-coded item ("Do you use words that might hurt immigrants?"), in order to increase the reliability of the scale. This is consistent with previous studies, which show that after the $7^{\text {th }}$ year of age children differentiate between ingroup and outgroup more in terms of positive than negative items (e.g., Bennett et al., 2004), possibly due to the endorsement of social norms against discrimination (see Rutland, Cameron, Milne, \& McGeorge, 2005).

2. Due to the relatively low reliability for the attitude measure collected prior to the intervention, we ran additional analyses by considering each item separately, or by not controlling for prior outgroup attitudes. In all cases, the results did not change.

3. We thank an anonymous reviewer for suggesting this potential improvement to the experimental design. 
HARRY POTTER AND ATTITUDES TOWARD STIGMATIZED GROUPS

\section{Acknowledgments}

We wish to thank Cristina Bonacini, Elen Bianchini, and the Institutes Scaruffi Levi

Tricolore (Reggio Emilia), Giovanni Pascoli and Giotto (Carpi, Modena) for their help in the organization of the study. We are also grateful to Gaia Davolio for her assistance in data collection. 
HARRY POTTER AND ATTITUDES TOWARD STIGMATIZED GROUPS

\section{References}

Aberson, C. L., \& Haag, S. C. (2007). Contact, perspective taking, and anxiety as predictors of stereotype endorsement, explicit attitudes, and implicit attitudes. Group Processes and Intergroup Relations, 10, 179-201.

Allport, G. W. (1954). The nature of prejudice. New York, NY: Addison-Wesley.

Alton, A. H. (2009). Playing the genre game: Generic fusions of the Harry Potter series. In E. E. Heilman (Ed.), Critical perspectives on Harry Potter ( $2^{\text {nd }}$ ed.) (pp. 199-223). New York, NY: Routledge/Taylor and Francis Group.

Andrighetto, L., Mari, S., Volpato, C., \& Behluli, B. (2012). Reducing competitive victimhood in Kosovo: The role of extended contact and common ingroup identity. Political Psychology, 33, 513-529.

Bandura, A. (1997). Self-efficacy: The exercise of control. New York, NY: Freeman. Bandura, A. (1999). Social cognitive theory of personality. In D. Cervone \& Y. Shoda (Eds.), The coherence of personality (pp. 185-241). New York, NY: Guilford Press.

Bandura, A. (2002). Social cognitive theory of mass communication. In J. Bryant \& D. Zillmann (Eds.), Media effects: Advances in theory and research $\left(2^{\text {nd }}\right.$ ed., pp. 121153). Hillsdale, NJ: Erlbaum.

Bandura, A., Ross, D. \& Ross, S.A. (1961) Transmission of aggression through imitation of aggressive models. Journal of Abnormal and Social Psychology, 63, $575-582$.

Batson, C. D. (2010). Empathy-induced altruistic motivation. In M. Mikulincer \& P. R. Shaver (Eds.), Prosocial motives, emotions, and behavior: The better angels of our nature (pp. 15-34). Washington, DC: American Psychological Association. 
HARRY POTTER AND ATTITUDES TOWARD STIGMATIZED GROUPS

Batson, C. D., Polycarpou, M. P., Harmon-Jones, E., Imhoff, H. J., Mitchener, E. C., Bednor, L. L... \& Highberger, L. (1997). Empathy and attitudes: Can feelings for a member of stigmatised group improve feelings toward the group? Journal of Personality and Social Psychology, 72, 105-118.

Beers, M. J., \& Apple, K. J. (2006). Intergroup conflict in the world of Harry Potter. In N. Mulholland (Ed.), The psychology of Harry Potter (pp. 33-44). Dallas, TX: BenBella Books.

Bennett, M., Barrett, M., Karakozov, R., Kipiani, G., Lyons, E., Pavlenko, V., \& Riazanova, T. (2004). Young children's evaluations of the ingroup and of outgroups: A multi-national study. Social Development, 13, 124-141.

Bilali, R., \& Vollhardt, J. R. (2013). Priming effects of a reconciliation radio drama on historical perspective-taking in the aftermath of mass violence in Rwanda. Journal of Experimental Social Psychology, 49, 144-151.

Brehm, J. W., \& Brehm, S. S. (1981). Psychological reactance: A theory of freedom and control. San Diego, CA: Academic Press.

Cameron, L., \& Rutland, A. (2006). Extended contact through story reading in school: Reducing children's prejudice toward the disabled. Journal of Social Issues, 62, 469488.

Cameron, L., Rutland, A., \& Brown, R. (2007). Promoting children's positive intergroup attitudes towards stigmatized groups: Extended contact and multiple classification skills training. International Journal of Behavioral Development, 31, 454-466. 
HARRY POTTER AND ATTITUDES TOWARD STIGMATIZED GROUPS

Cameron, L., Rutland, A., Brown, R., \& Douch, R. (2006). Changing children's intergroup attitudes toward refugees: Testing different models of extended contact. Child Development, 77, 1208-1219.

Cameron, L., Rutland, A., Hossain, R., \& Petley, R. (2011). When and why does extended contact work? The role of high quality direct contact and group norms in the development of positive ethnic intergroup attitudes amongst children. Group Processes and Intergroup Relations, 14, 193-206.

Capozza, D., Vezzali, L., Trifiletti, E., Falvo, R., \& Favara, I. (2010). Improving intergroup relationships within and outside the contact situation: The role of common ingroup identity and emotions of anxiety and empathy. Testing, Psychometrics, Methodology in Applied Psychology, 17, 17-36.

Cehajic, S., Brown, R., \& Castano, E. (2008). Forgive and forget? Antecedents and consequences of intergroup forgiveness in Bosnia and Herzegovina. Political Psychology, 29, 351-367.

Cristol, D., \& Gimbert, B. (2008). Racial perceptions of young children: A review of the literature post-1999. Early Childhood Education Journal, 36, 201-207.

Delzescaux, S. (2009). Harry Potter or the strange paths of the resistance. Nouvelle Revue de Psychosociologie, 7, 85-100.

Eller, A., Abrams, D., \& Zimmermann, A. (2011). Two degrees of separation: A longitudinal study of actual and perceived extended international contact. Group Processes and Intergroup Relations, 14, 175-191.

Esses, V. M., \& Dovidio, J. F. (2002). The role of emotions in determining willingness to engage in intergroup contact. Personality and Social Psychological Bulletin, 28, $1202-1214$. 
HARRY POTTER AND ATTITUDES TOWARD STIGMATIZED GROUPS

Eurobarometer (2012). Discrimination in the EU in 2012 (Publication No 393). European Commission.

Eyal, K., \& Rubin, A. M. (2003). Viewer aggression and homophily, identification, and parasocial relationships with television characters. Journal of Broadcasting and Electronic Media, 47, 77-98.

Fields, J.W. (2007). Harry Potter, Benjamin Bloom, and the sociological imagination. International Journal of Teaching and Learning in Higher Education, 19, 167-177.

Fisher, F. L. (1968). Influences of reading and discussion on the attitudes of fifth graders toward American Indians. Journal of Educational Research, 623, 130-134.

Franklin, N. (2006). The social dynamics of power and cooperation in the wizarding world. In N. Mulholland (Ed.), The psychology of Harry Potter (pp. 169-174). Dallas, TX: BenBella Books.

Galinsky, A. D., \& Ku, G. (2004). The effects of perspective taking on prejudice: The moderating role of self-evaluation. Personality and Social Psychology Bulletin, 30, 599-604.

Galinsky, A. D., Ku, G., \& Wang, C. S. (2005). Perspective-taking and self-other overlap: Fostering social bonds and facilitating social coordination. Group Processes and Intergroup Relations, 8, 109-124.

Galinsky, A. D., Maddux, W. W., Gilin, D., \& White, J. B. (2008). Why it pays to get inside the head of your opponent: The differential effects of perspective-taking and empathy in strategic interactions. Psychological Science, 19, 378-384.

Gomez, A., Tropp, L. R., \& Fernandez, S. (2011). When extended contact opens the door to future contact: Testing the effects of extended contact on attitudes and 
HARRY POTTER AND ATTITUDES TOWARD STIGMATIZED GROUPS

intergroup expectancies in majority and minority groups. Group Processes and Intergroup Relations, 14, 161-173.

Griesinger, E. (2002). Harry Potter and the 'deeper magic': Narrating hope in children's literature. Christianity and Literature, 51, 55-482.

Harwood, J., Paolini, S., Joyce, N., Rubin, M., \& Arroyo, A. (2011). Secondary transfer effects from imagined contact: Group similarity affects the generalization gradient. British Journal of Social Psychology, 50, 180-189.

Hayes, A. F. (2012). PROCESS: A versatile computational tool for observed variable mediation, moderation, and conditional process modeling. Retrieved from http://www.afhayes.com/public/process2012.pdf

Heilman, E. E. (Ed.) (2009). Critical perspectives on Harry Potter ( $2^{\text {nd }}$ ed.). New York, NY: Routledge/Taylor and Francis Group.

Hodson, G., Harry, H., \& Mitchell, A. (2009). Independent benefits of contact and friendship on attitudes toward homosexuals among authoritarians and highly identified heterosexuals. European Journal of Social Psychology, 39, 509-525.

Hodson, G., \& Hewstone, M. (Eds.) (2013). Advances in intergroup contact. New York, NY: Psychology Press.

Hong, S.-M., \& Faedda, S. (1996). Refinement of the Hong psychological reactance scale. Educational and Psychological Measurement, 56, 173-182.

Johnson, D. R., Huffman, B. L., \& Jasper, D. M. (2014). Changing race boundary perception by reading narrative fiction. Basic and Applied Social Psychology, 36, 8390. 
HARRY POTTER AND ATTITUDES TOWARD STIGMATIZED GROUPS

Johnson, D. R., Jasper, D. M., Griffin, S., \& Huffman, B. L. (2013). Reading narrative fiction reduces Arab-Muslim prejudice and offers a safe haven from intergroup anxiety. Social Cognition, 31, 578-598.

Johnson, P. J., \& Aboud, F. E. (2013). Modifying ethnic attitudes in young children: The impact of communicator race and message strength. International Journal of Behavioral Development, 37, 182-191.

Kaufman, G. F., \& Libby, L. K. (2012). Changing beliefs and behavior through experience-taking. Journal of Personality and Social Psychology, 103, 1-19.

Kelman, H. C., \& Fisher, R. J. (2003). Conflict analysis and resolution. In D. O. Sears, L. Huddy, \& R. Jervis (Eds.), Political psychology (pp. 315-356). London, UK: Oxford University Press.

Kidd, D. C., \& Castano, E. (2013). Reading literary fiction improves theory of mind. Science, 342, 377-380.

Kite, M. E., \& Whitley, B. E. (1996). Sex differences in attitudes toward homosexual persons, behaviors, and civil rights: A meta-analysis. Personality and Social Psychology Bulletin, 22, 336-353.

Knapp, N. F. (2003). In defence of Harry Potter: An apologia. School Libraries Worldwide (International Association of School Librarianship), 9, 78-91.

Liebkind, K., \& McAlister, A. L. (1999). Extended contact through peer modelling to promote tolerance in Finland. European Journal of Social Psychology, 29, 765-780.

Lolliot, S., Schmid, K., Hewstone, M., Al Ramiah, A., Tausch, N., \& Swart, H. (2013). Generalized effects of intergroup contact: The secondary transfer effect. In G. Hodson \& M. Hewstone (Eds.), Advances in intergroup contact (pp. 81-112). London, UK: Psychology Press. 
HARRY POTTER AND ATTITUDES TOWARD STIGMATIZED GROUPS

McLaren, L. M. (2003). Anti-immigrant prejudice in Europe: Contact, threat perception, and preferences for the expulsion of migrants. Social Forces, 81, 909-936.

Meleady, R., Hopthrow, T., \& Crisp, R. J. (2013). The group discussion effect: Integrative processes and suggestions for implementation. Personality and Social Psychology Review, 17, 56-71.

Mulholland, N. (Ed.) (2006). The psychology of Harry Potter. Dallas, TX: BenBella Books.

Muller, D., Judd, C. M., \& Yzerbyt, V. Y. (2005). When moderation is mediated and mediation is moderated. Journal of Personality and Social Psychology, 89, 852-863.

Nier, J. A., \& Gaertner, S. L. (2012). The challenge of detecting contemporary forms of discrimination. Journal of Social Issues, 68, 207-220.

Ortiz, M., \& Harwood, J. (2007). A social cognitive theory approach to the effect of mediated intergroup contact on intergroup attitudes. Journal of Broadcasting and Electronic Media, 51, 615-631.

Paluck, E. L., \& Green, D. P. (2009). Prejudice reduction: What works? A critical look at evidence from the field and the laboratory. Annual Review of Psychology, 60, 339367.

Paolini, S., Hewstone, M., Cairns, E., \& Voci, A. (2004). Effects of direct and indirect cross-group friendships on judgements of catholics and protestants in Northern Ireland: The mediating role of an anxiety-reduction mechanism. Personality and Social Psychology Bulletin, 30, 770-786.

Patrick, C. J., \& Patrick, S. K. (2006). Exploring the dark side. In N. Mulholland (Ed.), The psychology of Harry Potter (pp. 221-232). Dallas, TX: BenBella Books. 
HARRY POTTER AND ATTITUDES TOWARD STIGMATIZED GROUPS

Pehrson, S., Brown, R., \& Zagefka, H. (2009). When does national identification lead to the rejection of immigrants? Cross-sectional and longitudinal evidence for the role of essentialist ingroup definitions. British Journal of Social Psychology, 48, 61-76.

Pereira, C., Vala, J., \& Costa-Lopez, R. (2010). From prejudice to discrimination: The legitimizing role of perceived threat in discrimination against immigrants. European Journal of Social Psychology, 40, 1231-1250.

Pettigrew, T. F. (2009). Secondary transfer effect of contact: Do intergroup contact effects spread to noncontacted outgroups? Social Psychology, 40, 55-65.

Pettigrew, T. F., \& Tropp, L. R. (2008). How does intergroup contact reduce prejudice? Meta-analytic tests of three mediators. European Journal of Social Psychology, 38, 922-934.

Pettigrew, T. F., \& Tropp, L. (2011). When groups meet: The dynamics of intergroup contact. New York, NY: Psychology Press.

Preacher, K. J., Rucker, D. D., \& Hayes, A. F. (2007). Addressing moderated mediation hypotheses: Theory, methods, and prescriptions. Multivariate Behavioral Research, $42,185-227$

Premack, D., \& Woodruff, G. (1978). Does the chimpanzee have a theory of mind? Behavioral and Brain Sciences, 4, 515-526.

Rowling, J. K. (1998). Harry Potter and the Chamber of Secrets. London, UK: Bloomsbury.

Rutland, A., Cameron, L., Milne, A., \& McGeorge, P. (2005). Social norms and selfpresentation: Children's implicit and explicit intergroup attitudes. Child Development, 76, 451-466. 
HARRY POTTER AND ATTITUDES TOWARD STIGMATIZED GROUPS

Saxe, R., Carey, S., \& Kanwisher, N. (2004). Understanding other minds: Linking developmental psychology and functional neuroimaging. Annual Review of Psychology, 55, 87-124.

Schiappa, E., Gregg, P. B., \& Hewes, D. E. (2005). The parasocial contact hypothesis. Communication Monographs, 72, 92-115.

Schmid, K., Hewstone, M., Kupper, B., Zick, A., \& Wagner, U. (2012). Secondary transfer effects of intergroup contact: A cross-national comparison in Europe. Social Psychology Quarterly, 75, 28-51.

Senland, A., \& Vozzola, E. (2007). Christian perspectives on Harry Potter: Tool of Satan or Christian parable? Journal of Research in Character Education, 5, 149-165.

Sidanius, J., \& Pratto, F. (1999). Social dominance: An intergroup theory of social hierarchy and oppression. New York: Cambridge University Press.

Stasiuk, K., \& Bilewicz, M. (2013). Extending contact across generations: Comparison of direct and ancestral intergroup contact effects on current attitudes toward outgroup members. Journal of Community and Applied Social Psychology, 23, 481-491.

Stephan, W. G., \& Finlay, K. (1999). The role of empathy in improving intergroup relations. Journal of Social Issues, 55, 729-743.

Swart, H., Hewstone, M., Christ, O., \& Voci, A. (2011). Affective mediators of intergroup contact: A three-wave longitudinal study in South Africa. Journal of Personality and Social Psychology, 101, 1221-1238.

Tajfel, H., \& Turner, J. C. (1979). An integrative theory of intergroup conflict. In W. G. Austin \& S. Worchel (Eds.), The social psychology of intergroup relations (pp. 3347). Monterey, CA: Brooks/Cole. 
HARRY POTTER AND ATTITUDES TOWARD STIGMATIZED GROUPS

Tausch, N., Hewstone, M., Kenworthy, J. B., Psaltis, C., Schmid, K., Popan, J. R... \& Hughes, J. (2010). Secondary transfer effects of intergroup contact: Alternative accounts and underlying processes. Journal of Personality and Social Psychology, 99, 282-302.

Tausch, N., Hewstone, M., Schmid, K., Hughes, J., \& Cairns, E. (2011). Extended contact as a function of closeness of relationship with ingroup contacts. Group Processes and Intergroup Relations, 14, 239-254.

Turner, R. N., Hewstone, M., \& Voci, A. (2007). Reducing explicit and implicit outgroup prejudice via direct and extended contact: The mediating role of selfdisclosure and intergroup anxiety. Journal of Personality and Social Psychology, 93, 369-388.

Turner, R. N., Hewstone, M., Voci, A., Paolini, S., \& Christ, O. (2007). Reducing prejudice via direct and extended cross-group friendship. European Review of Social Psychology, 18, 212-255.

Turner, R. N., Hewstone, M., Voci, A., \& Vonofakou, C. (2008). A test of the extended contact hypothesis: The mediating role of intergroup anxiety, perceived ingroup and outgroup norms, and inclusion of the outgroup in the self. Journal of Personality and Social Psychology, 95, 843-860.

Turner, R. N., Tam, T., Hewstone, M., Kenworthy, J., \& Cairns, E. (2013). Contact between Catholic and Protestant schoolchildren in Northern Ireland. Journal of Applied Social Psychology, 43 (Suppl. 2), E216-E228.

Vescio, T. K., Sechrist, G. B., \& Paolucci, M. P. (2003). Perspective taking and prejudice reduction: The mediational role of empathy arousal and situational attributions. European Journal of Social Psychology, 33, 455-472. 
HARRY POTTER AND ATTITUDES TOWARD STIGMATIZED GROUPS

Vezzali, L. \& Giovannini, D. (2012). Secondary transfer effect of intergroup contact: The role of intergroup attitudes, intergroup anxiety and perspective-taking. Journal of Community and Applied Social Psychology, 22, 125-144.

Vezzali, L., Giovannini, D., \& Capozza, D. (2010). Longitudinal effects of contact on intergroup relations: The role of majority and minority group membership and intergroup emotions. Journal of Community and Applied Social Psychology, 20, 462479.

Vezzali, L., Giovannini, D., \& Capozza, D. (2012). Social antecedents of children's implicit prejudice: Direct contact, extended contact, explicit and implicit teachers' prejudice. European Journal of Developmental Psychology, 9, 569-581.

Vezzali, L., Hewstone, M., Capozza, D., Giovannini, D., \& Wöelfer, R. (2014). Improving intergroup relations with extended and vicarious contact: An integrative review. Under review.

Vezzali, L., Stathi, S., \& Giovannini, D. (2012). Indirect contact through book reading: Improving adolescents' attitudes and behavioral intentions toward immigrants. Psychology in the Schools, 49, 148-162.

Vorauer, J. D., \& Sasaki, S. J. (2012). The pitfalls of empathy as a default intergroup interaction strategy: Distinct effects of trying to empathize with a lower status outgroup member who does versus does not express distress. Journal of Experimental Social Psychology, 48, 519-524.

Wagner, U., Christ, O., Wolf, C., van Dick, R., Stellmacher, J., Schluter, E., \& Zick, A. (2008). Social and political context effects on intergroup contact and intergroup attitudes. In U. Wagner, L. R. Tropp, G. Finchilescu, \& C. Tredoux (Eds.), Emerging 
HARRY POTTER AND ATTITUDES TOWARD STIGMATIZED GROUPS

research directions for improving intergroup relations: Building on the legacy of Thomas F. Pettigrew (pp. 195-209) New York, NY: Wiley.

West, K., \& Hewstone, M. (2012). Relatively socially acceptable prejudice within and between societies. Journal of Community and Applied Social Psychology, 22, 269282.

Whitney, M. P., Vozzola, E. C., \& Hofmann, J. (2005). Children's moral reading of Harry Potter: Are children and adults reading the same books? Journal of Research in Character Education, 3, 1-24.

Wikipedia (2014). List of best-selling books. Retrieved February $21^{\text {st }} 2014$ from http://en.wikipedia.org/wiki/List_of_best-selling_books

Worthy, J., Moorman, M., \& Turner, M. (1999). What Johnny likes to read is hard to find in school. Reading Research Quarterly, 34, 12-27.

Wright, S. C., Aron, A., McLaughlin-Volpe, T., \& Ropp, S. A (1997). The extended contact effect: Knowledge of cross-group friendships and prejudice. Journal of Personality and Social Psychology, 73, 73-90.

Zick, A., Pettigrew, J. F., \& Wagner, U. (2008). Ethnic prejudice and discrimination in Europe. Journal of Social Issues, 64, 233-251.

Zitek, E. M., \& Hebl, M. R. (2007). The role of social norm clarity in the influenced expression of prejudice over time. Journal of Experimental Social Psychology, 43, 867-876. 
HARRY POTTER AND ATTITUDES TOWARD STIGMATIZED GROUPS

Table 1. Means and standard deviations for participants in the experimental and control conditions (Study 1).

\begin{tabular}{|c|c|c|c|c|}
\hline \multirow[b]{3}{*}{ Measure } & \multicolumn{4}{|c|}{ Condition } \\
\hline & \multicolumn{2}{|c|}{$\begin{array}{l}\text { Experimental } \\
\quad(n=17)\end{array}$} & \multicolumn{2}{|c|}{$\begin{array}{l}\text { Control } \\
(n=17)\end{array}$} \\
\hline & $M$ & $S D$ & $M$ & $S D$ \\
\hline $\begin{array}{l}\text { Outgroup attitudes } \\
\text { (administered before the } \\
\text { intervention) }\end{array}$ & 2.39 & 0.80 & 1.94 & 0.88 \\
\hline Outgroup attitudes & 2.20 & 0.98 & 1.76 & 0.85 \\
\hline Identification with Harry Potter & 3.38 & 0.89 & 3.26 & 1.09 \\
\hline Identification with Voldemort & 1.85 & 1.58 & 1.88 & 1.26 \\
\hline
\end{tabular}




\section{HARRY POTTER AND ATTITUDES TOWARD STIGMATIZED GROUPS}

Table 2. Means, standard deviations and correlations among variables (Study 2).

\begin{tabular}{|c|c|c|c|c|c|c|c|c|c|c|c|}
\hline & 1 & 2 & 3 & 4 & 5 & 6 & 7 & 8 & 9 & 10 & 11 \\
\hline $\begin{array}{l}\text { 1. Number of Harry Potter books } \\
\text { read }\end{array}$ & - & & & & & & & & & & \\
\hline $\begin{array}{l}\text { 2. Number of Harry Potter films } \\
\text { watched }\end{array}$ & $.36 * * *$ & - & & & & & & & & & \\
\hline 3. Identification with Harry Potter & $.24 * *$ & $.34 * * *$ & - & & & & & & & & \\
\hline 4. Identification with Voldemort & -.00 & .11 & .02 & - & & & & & & & \\
\hline 5. Outgroup attitudes & .05 & .14 & .10 & -.04 & - & & & & & & \\
\hline 6. Quantity of contact & -.12 & -.02 & .06 & -.04 & $.32 * * *$ & - & & & & & \\
\hline 7. Quality of contact & -.08 & .12 & .07 & -.02 & $.63 * * *$ & $.53 * * *$ & - & & & & \\
\hline $\begin{array}{l}\text { 8. Number of books read per year } \\
\text { (excluding Harry Potter books) }\end{array}$ & $.22 *$ & .10 & .12 & $-.16^{\dagger}$ & $.32 * * *$ & .12 & $.26 * *$ & - & & & \\
\hline $\begin{array}{l}\text { 9. Number of hours spent each day } \\
\text { on television }\end{array}$ & -.08 & .04 & .08 & .09 & .05 & .02 & .03 & -.14 & - & & \\
\hline 10. Gender $(1=$ male $; 2=$ female $)$ & $-.16^{\dagger}$ & -.10 & -.00 & $-.24 * *$ & $.42 * * *$ & $.24 * *$ & $.37 * * *$ & $.32 * * *$ & -.11 & - & \\
\hline 11. Age (in years) & -.04 & -.11 & -.13 & -.04 & $.18^{\dagger}$ & $.33 * * *$ & $.28 * *$ & .06 & $.16^{\dagger}$ & .15 & - \\
\hline$M$ & 1.80 & 4.86 & 1.62 & 1.40 & 57.74 & 1.53 & 2.33 & 2.45 & 2.41 & I & 17.39 \\
\hline$S D$ & 2.57 & 2.45 & 0.69 & 0.83 & 32.02 & 0.88 & 1.22 & 1.14 & 0.76 & I & 0.94 \\
\hline
\end{tabular}

Note. The response scale for all measures ranged from 1 to 5, with the exception of Number of Harry Potter books read and films watched (scale 0-7), Outgroup attitudes (scale 0-100). Identification with Harry Potter and identification with Voldemort were square-root transformed to approximate normality; Means and standard deviations refer instead to non-transformed data.

${ }^{\dagger} p<.10 .{ }^{*} p<.05 .{ }^{* *} p \leq .01 .{ }^{* * *} p \leq .001$. 


\section{HARRY POTTER AND ATTITUDES TOWARD STIGMATIZED GROUPS}

Table 3. Means, standard deviations and correlations among variables (Study 3).

\begin{tabular}{|c|c|c|c|c|c|c|c|c|c|c|c|c|}
\hline & 1 & 2 & 3 & 4 & 5 & 6 & 7 & 8 & 9 & 10 & 11 & 12 \\
\hline $\begin{array}{l}\text { 1. Number of Harry Potter books } \\
\text { read }\end{array}$ & - & & & & & & & & & & & \\
\hline $\begin{array}{l}\text { 2. Number of Harry Potter films } \\
\text { watched }\end{array}$ & $.57 * * *$ & - & & & & & & & & & & \\
\hline 3. Identification with Harry Potter & $.21^{\dagger}$ & $.34 * *$ & - & & & & & & & & & \\
\hline 4. Identification with Voldemort & .09 & .05 & $.24 *$ & - & & & & & & & & \\
\hline 5. Perspective-taking & -.00 & $-.28 *$ & -.11 & -.15 & - & & & & & & & \\
\hline 6. Outgroup attitudes & -.10 & $-.26^{*}$ & .05 & $-.36 * * *$ & $.60 * * *$ & - & & & & & & \\
\hline 7. Quantity of contact & .00 & -.14 & -.10 & -.02 & $.52 * * *$ & $.46^{* * *}$ & - & & & & & \\
\hline 8. Quality of contact & -.04 & $-.34 * *$ & $-.26 *$ & .00 & $.53 * * *$ & $.46^{* * *}$ & $.60 * * *$ & - & & & & \\
\hline $\begin{array}{l}\text { 9. Number of books read per year } \\
\text { (excluding Harry Potter books) }\end{array}$ & $.44 * * *$ & $.30^{*}$ & .14 & -.19 & .08 & -.00 & -.12 & -.13 & - & & & \\
\hline $\begin{array}{l}\text { 10. Number of hours spent each } \\
\text { day on television }\end{array}$ & $-.27 *$ & -.15 & .07 & .17 & .05 & .08 & .06 & -.03 & $-.22^{\dagger}$ & - & & \\
\hline 11. Gender $(1=$ male $; 2=$ female $)$ & -.16 & -.12 & -.18 & $-.27 *$ & .03 & .06 & .04 & -.05 & .11 & .09 & & \\
\hline 12. Age (in years) & -.14 & -.11 & .15 & -.01 & .02 & .07 & -.03 & .09 & .11 & -.19 & $-.25 *$ & - \\
\hline$M$ & 4.44 & 5.52 & 2.20 & 1.34 & 3.23 & 3.69 & 2.65 & 3.75 & 3.39 & 2.34 & I & 20.15 \\
\hline$S D$ & 2.61 & 1.90 & 1.09 & 0.83 & 0.82 & 0.85 & 1.29 & 0.94 & 1.37 & 0.94 & l & 3.96 \\
\hline
\end{tabular}

Note. The response scale for all measures ranged from 1 to 5 , with the exception of Number of Harry Potter books read and films watched (scale 0-7). Identification with

Voldemort was square-root transformed to approximate normality; The mean and the standard deviation refer instead to non-transformed data.

${ }^{\dagger} p \leq .08 . * p<.05 . * * p \leq .01 . * * * p \leq .001$. 


\section{HARRY POTTER AND ATTITUDES TOWARD STIGMATIZED GROUPS}

Table 4. Regression coefficients evaluating the effects of Harry Potter books read and films watched on perspective-taking and attitudes toward refugees depending on the level of character identification (Study 3).

Moderator (character identification)

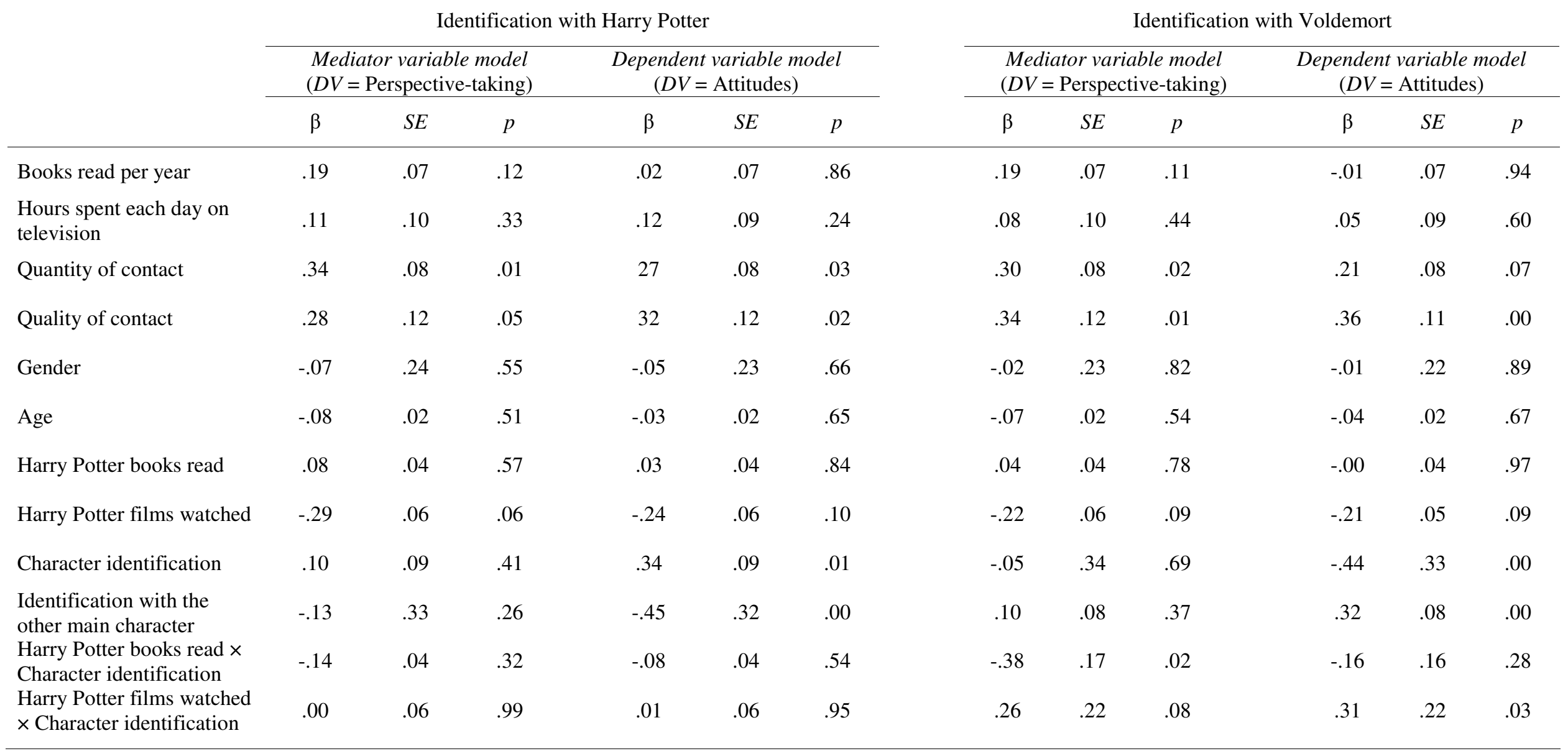

